
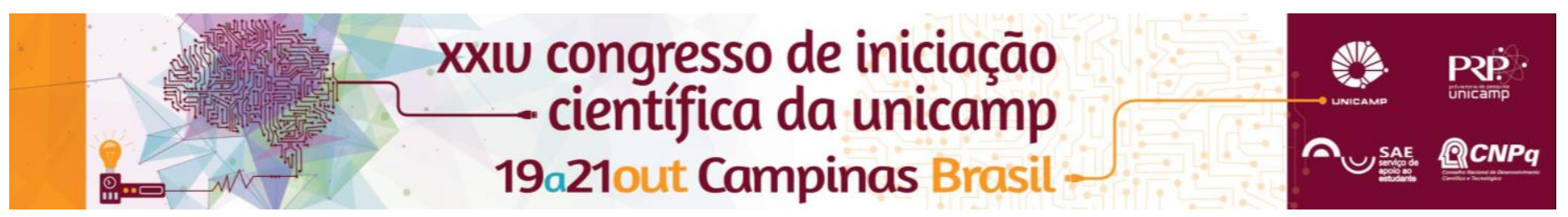

\title{
Freud e os limites da filosofia da consciência
}

\section{Adilson Grego Junior}

\section{Resumo}

Por meio do exame da noção de inconsicente, elaborada pelo médico vienense Sigmud Freud, podemos notar uma ruptura com o discurso sobre o psiquismo proferido pelos médicos e psicólogos do período. Freud, em contraposição ao discurso da consciência de sua época, compreende que o psiquismo humano não opera apenas no nível da consciência, mas que há também uma outra instância psíquica independente da consciência trabalhando com mecanismos próprios de funcionamento.

\section{Palavras-chave:}

Freud, inconsciente, psicanálise.

\section{Introdução}

Freud, no decorrer de sua trajetória, foi levado a reconhecer certas limitações teóricas e terapêuticas nos discursos da medicina e da psicologia da época. Tais discursos, que concebiam o psiquismo humano exclusivamente voltado ao âmbito da consciência, fundamentavam-se na filosofia do cogito cartesiano, onde o psiquismo humano encontrava-se integralmente atrelado ao registro da consciência. Ao perceber a insuficiência das terapêuticas pautadas no discurso da consciência, Freud, através de minucioso estudo da sintomatologia de suas pacientes, desenvolve a noção de inconsciente. Desse modo, nosso trabalho consistirá fundamentalmente em verificar de que modo Freud percebe as limitações do discurso da consciência, como isso o leva a formular a noção de inconsciente e de que maneira esse novo psiquismo elaborado por Freud pode representar uma desconstrução dos pilares da filosofia da consciência.

\section{Resultados e Discussão}

Freud, influenciado pelo dispositivo teórico de Jean-Martin Charcot, Hyppolyte Bernheim e Josef Breuer, com a finalidade de encontrar tratamentos terapêuticos mais satisfatórios para suas pacientes, através do estudo sistemático da sintomatologia destas, percebe que há diversos acontecimentos que não ocorrem de forma consciente, mas apenas sob o luscofusco do estado hipnóide. Tal evento leva o médico vienense a buscar as causas das patologias mentais fora da visão anato-clínica estabelecida pela medicina da época e também, posteriormente, fora do discurso da consciência, isto é, dos estritos registros da consciência que era compreendida como absoluta no psiquismo humano. O estabelecimento da noção de inconsciente vêm para dissolver a questão desses dois paradigmas e nos trazer algo inaudito.

Embora a ideia de um psiquismo inconsciente já tenha sido trabalhada por diversos autores em vários períodos - até mesmo muito anteriores a Freud - o que a psicanálise freudiana nos traz de insólito é o estabelecimento do inconsciente enquanto um sistema psíquico, isto é, um composto do aparelho psíquico completamente independente da consciência, que opera através de mecanismos singulares. Em vista disso, ao tratar da temática do inconsciente, temos que ter em mente que tal noção pode ser compreendida de dois modos distintos, a saber, de modo adjetivo ou descritivo e de modo sistemático ou tópico. Ao tratarmos do inconsciente da primeira maneira, compreendemos tudo aquilo que não é consciente, que não está em foco na consciência, no entanto, de modo algum isso designa o inconsciente como um sistema psíquico autônomo que opera com seus próprios mecanismos de funcionamento, tal como descreve a vertente sistemática.

\section{Conclusões}

Freud, através do estabelecimento da noção de inconsciente - compreendida em sua vertente sistemática - parece realmente subverter os saberes sobre o psiquismo humano estabelecidos até então.

\section{Agradecimentos}

Universidade Estadual de Campinas - Unicamp $\mathrm{PIBIC}-\mathrm{CNPq}$.

GARCIA-ROZA, Luiz Alfredo. Introdução à metapsicologia freudiana 3: Narcisismo, pulsão, recalque, inconsciente (1914 - 1917) - $7^{\mathrm{a}}$ ed. - Rio de Janeiro: Jorge Zahar Ed., 2008.

FREUD, Sigmund. A interpretação dos sonhos. Rio de Janeiro: Imago Ed., 2001. Edição Comemorativa 100 anos. Tradução de Walderedo Ismael de Oliveira. 